\title{
Molecular and Crystal Structure of 1-(4-Chlorophenyl)-5-(2-dimethylaminovinyl)-1H-tetrazole: a Vinylogous 5-Amino-1H-tetrazole Derivative
}

\author{
Joachim Sieler, ${ }^{a}$ Knut Maartmann-Moe ${ }^{b}$ and Gerhard W. Fischer ${ }^{c}$ \\ aSektion Chemie der Karl-Marx-Universität Leipzig, Talstrasse 35, Leipzig, 7010, GDR, 'Department of Chemistry, University of \\ Bergen, Allegaten 41, N-5000 Bergen, Norway and 'Forschungsstelle für chemische Toxikologie der Akademie der Wissenschaften \\ der DDR, Permoserstrasse 15, Leipzig, 7050, GDR
}

\begin{abstract}
Sieler, J., Maartmann-Moe, K. and Fischer, G. W., 1989. Molecular and Crystal Structure of 1-(4-Chlorophenyl)-5-(2-dimethylaminovinyl)- $1 H$-tetrazole: a Vinylogous 5-Amino-1H-tetrazole Derivative. - Acta Chem Scand. 43: 298-300.
\end{abstract}

As has been recently shown ${ }^{1} 3$-chloropropeniminium salts 1 react with excess sodium azide in refluxing alcohols to give a mixture of the isomeric dialkylaminovinyl- $1 H$-tetrazoles 2 and 3 (Scheme 1). However, as a main product only one type of isomer is isolable in pure, crytalline form. In order to determine its structure, the $p$-chlorophenyl-substituted dimethylaminovinyl- $1 \mathrm{H}$-tetrazole $\mathrm{C}_{11} \mathrm{H}_{12} \mathrm{ClN}_{5}$, obtained from $1 \mathrm{R}^{1}=\mathrm{R}^{2}=\mathrm{CH}_{3}, \mathrm{AR}=4-\mathrm{ClC}_{6} \mathrm{H}_{4}, \mathrm{X}=\mathrm{ClO}_{4}$ and excess sodium azide, ${ }^{1}$ was investigated by $\mathrm{X}$-ray crystallography.
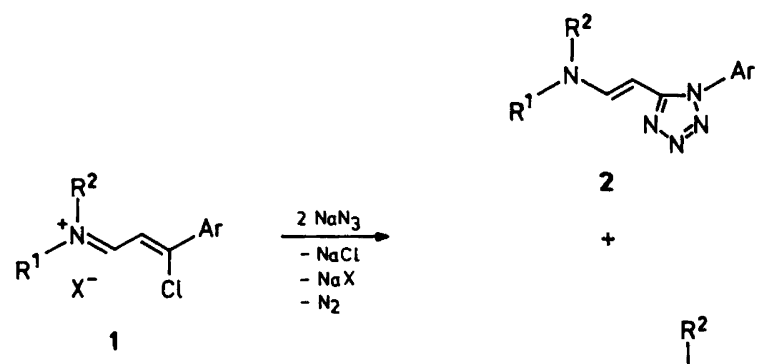

2

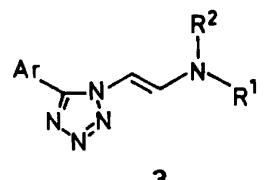

3

Structure determination. The tetrazole derivative $\mathrm{C}_{11} \mathrm{H}_{12} \mathrm{ClN}_{5}$ is a stable colorless compound, m.p. 144 $145^{\circ} \mathrm{C}$. Suitable crystals were obtained by recrystallization from benzene. Unit-cell dimensions and intensity data were measured on an automatic Enraf-Nonius CAD4 diffractometer using a graphite monochromator and Mo $K_{\alpha}$ radiation $(\lambda=0.71069 \AA)$. The unit-cell dimensions were determined from 25 reflections $\left(9^{\circ}<\theta<21^{\circ} \mathrm{C}\right)$ at room temperature $\left(18^{\circ} \mathrm{C}\right)$. A crystal of dimensions $0.20 \times 25 \times$ $0.30 \mathrm{~mm}$ was used for all X-ray measurements.
Crystal data. $\mathrm{C}_{11} \mathrm{H}_{12} \mathrm{ClN}_{5} M_{\mathrm{F}} 249.7$, triclinic, space group $P \overline{1}$, colorless prisms, $a=7.676(1), b=8.774(1), c=$ 10.022(1) $\AA, \alpha=66.93(1), \beta=86.28(1), \gamma=85.60(5)^{\circ}, V$ $=618.7 \AA^{3}, D_{\mathrm{c}}=1.34 \mathrm{~g} \mathrm{~cm}^{-3}, D_{\mathrm{m}}=1.33 \mathrm{~g} \mathrm{~cm}^{-3}$ (flotation), $Z=2, \mu=2.92 \mathrm{~cm}^{-1}$ (Mo $\left.K_{\alpha}\right)$.

Intensity data were measured by the $\omega$-scan technique. A total of 2984 unique reflections were recorded in the range $1^{\circ}<\theta<28^{\circ}(h:-11 \rightarrow 11, k:-11 \rightarrow 11, l: 0 \rightarrow 12)$. The 2091 reflections with $\left|F_{\mathrm{o}}\right|>2 \sigma_{F}$, where $\sigma_{F}=\sigma_{\mathrm{I}}(\mathrm{ILp})^{-1 / 2}$, were included in the refinement with weight $w=1 / \sigma_{\mathrm{F}}^{2}$. The structure was solved by direct methods using the program MITHRIL. ${ }^{2}$ Structure refinement was carried out by means of The Glasgow X-ray crystallographic package. ${ }^{3}$

The hydrogen atoms were geometrically placed and included in the full-matrix least-squares refinement with isotropic temperature factors and fixed coordinates. The refinement converged at $R=\Sigma\left(\left|F_{\mathrm{o}}\right|-\left|F_{\mathrm{c}}\right|\right) / \Sigma\left|F_{\mathrm{o}}\right|=0.058, R_{\mathrm{w}}$ $=\left[\Sigma w\left(\left|F_{\mathrm{o}}\right|-\left|F_{\mathrm{c}}\right|\right)^{2}\right]^{1 / 2}=0.065$. The maximum and minimum peaks in the final difference map are 0.39 and -0.43 e $\AA^{3}$, respectively; maximum least-squares shift to e.s.d. ratio in the final cycle 0.01 ; average shift to e.s.d. ratio 0.001 .

Final coordinates and isotropic temperature factors are listed in Table 1. A table with the anisotropic temperature factors for the non-hydrogen atoms and lists of structure factors are available on request from the authors (J. S.).

\section{Discussion}

The molecular structure of the title compound is shown in Figure 1; bond distances and bond angles are given in Table 2. The most interesting aspect of the structure is that the aryl group is located at the $\mathrm{N}(1)$ position and that the $E$ dialkylaminovinyl group is located at the ring carbon atom $\mathrm{C}(1)$ of the heterocycle, i.e. the compound proves to be (E)-1-(4-chlorophenyl)-5-(2-dimethylaminovinyl)- $H$-tetrazole $\left(2 ; \mathrm{R}^{1}=\mathrm{R}^{2}=\mathrm{CH}_{3}, \mathrm{Ar}=4-\mathrm{ClC}_{6} \mathrm{H}_{4}\right)$. This shows that 
Table 1. Fractional coordinates in $\mathrm{C}_{11} \mathrm{H}_{12} \mathrm{CIN}_{5}$. Estimated standard deviations are given in parentheses.

\begin{tabular}{lllll}
\hline Atom & \multicolumn{1}{l}{$x / a$} & $y / b$ & \multicolumn{1}{l}{$z / c$} & $U$ \\
\hline $\mathrm{Cl}$ & $0.19385(11)$ & $0.39951(13)$ & $0.25499(12)$ & $0.115(1)$ \\
$\mathrm{C}(1)$ & $-0.6172(3)$ & $0.8167(3)$ & $0.1185(3)$ & $0.050(1)$ \\
$\mathrm{C}(2)$ & $-0.6043(3)$ & $0.8112(3)$ & $-0.0216(3)$ & $0.053(1)$ \\
$\mathrm{C}(3)$ & $-0.7272(3)$ & $0.8912(3)$ & $-0.1191(3)$ & $0.055(1)$ \\
$\mathrm{C}(4)$ & $-0.5883(4)$ & $0.8182(4)$ & $-0.3112(3)$ & $0.085(2)$ \\
$\mathrm{C}(5)$ & $-0.8589(5)$ & $1.0018(6)$ & $-0.3532(4)$ & $1.106(3)$ \\
$\mathrm{C}(6)$ & $-0.3296(3)$ & $0.6690(3)$ & $0.2270(3)$ & $0.051(1)$ \\
$\mathrm{C}(7)$ & $-0.2174(3)$ & $0.7108(3)$ & $0.1063(3)$ & $0.055(1)$ \\
$\mathrm{C}(8)$ & $-0.0570(3)$ & $0.6272(3)$ & $0.1142(3)$ & $0.065(1)$ \\
$\mathrm{C}(9)$ & $-0.0100(3)$ & $0.5034(3)$ & $0.2444(3)$ & $0.070(1)$ \\
$\mathrm{C}(10)$ & $-0.1202(4)$ & $0.4610(4)$ & $0.3652(3)$ & $0.076(2)$ \\
$\mathrm{C}(11)$ & $-0.2815(4)$ & $0.5441(4)$ & $0.3570(3)$ & $0.067(2)$ \\
$\mathrm{N}(1)$ & $-0.4964(3)$ & $0.7540(2)$ & $0.2225(2)$ & $0.051(1)$ \\
$\mathrm{N}(2)$ & $-0.5581(3)$ & $0.7834(3)$ & $0.3416(2)$ & $0.068(2)$ \\
$\mathrm{N}(3)$ & $-0.7083(3)$ & $0.8609(3)$ & $0.3090(2)$ & $0.073(2)$ \\
$\mathrm{N}(4)$ & $-0.7503(3)$ & $0.8841(3)$ & $0.1733(2)$ & $0.063(1)$ \\
$\mathrm{N}(5)$ & $-0.7314(3)$ & $0.8973(3)$ & $-0.2541(2)$ & $0.068(1)$ \\
$\mathrm{H}(2)$ & -0.49493 & 0.74253 & -0.05020 & $0.063(7)$ \\
$\mathrm{H}(3)$ & -0.83389 & 0.95719 & -0.08431 & $0.079(9)$ \\
$\mathrm{H}(7)$ & -0.25524 & 0.80989 & 0.00528 & $0.063(7)$ \\
$\mathrm{H}(8)$ & 0.03125 & 0.65784 & 0.01942 & $0.080(9)$ \\
$\mathrm{H}(10)$ & -0.08090 & 0.36352 & 0.46657 & $0.10(1)$ \\
$\mathrm{H}(11)$ & -0.36967 & 0.51147 & 0.45189 & $0.09(1)$ \\
$\mathrm{H}(4 \mathrm{~A})$ & -0.59163 & 0.82300 & -0.41966 & $0.11(1)$ \\
$\mathrm{H}(4 \mathrm{~B})$ & -0.58005 & 0.68955 & -0.23992 & $0.10(1)$ \\
$\mathrm{H}(4 \mathrm{C})$ & -0.47105 & 0.87401 & -0.30534 & $0.11(1)$ \\
$\mathrm{H}(5 \mathrm{~A})$ & -0.86221 & 1.00659 & -0.46170 & $0.24(3)$ \\
$\mathrm{H}(5 \mathrm{~B})$ & -0.84277 & 1.12613 & -0.36296 & $0.25(3)$ \\
$\mathrm{H}(5 \mathrm{C})$ & -0.98453 & 0.96384 & -0.30231 & $0.23(3)$ \\
\hline & & & &
\end{tabular}

the reaction of 3-chloropropeniminium salts 1 with excess sodium azide results predominantly in tetrazole derivatives of structure 2 as the main isolable products.

Compounds of type 2 are vinylogous 5-amino- $1 \mathrm{H}$-tetrazoles, and are suggested to be hybrids of the resonance structures $\mathrm{A}$ and $\mathrm{B} .{ }^{5}$ Analogously, the system 2 may be described as a resonance hybrid of structures $C$ and $D$ (Scheme 2). The relatively short bond lengths $C(1)-C(2)$ and $\mathrm{C}(3)-\mathrm{N}(5)$ suggest a certain contribution from form $\mathrm{D}$, although form $\mathrm{C}$ must be regarded as the major contributor. Also, the $\mathrm{C}(1)-\mathrm{N}(4)$ bond length [1.335(3) $\AA]$ is significantly shorter than the $\mathrm{C}(1)-\mathrm{N}(1)$ bond length $[1.360(3)$

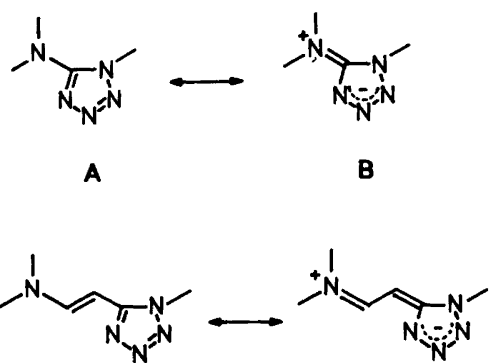

C

D

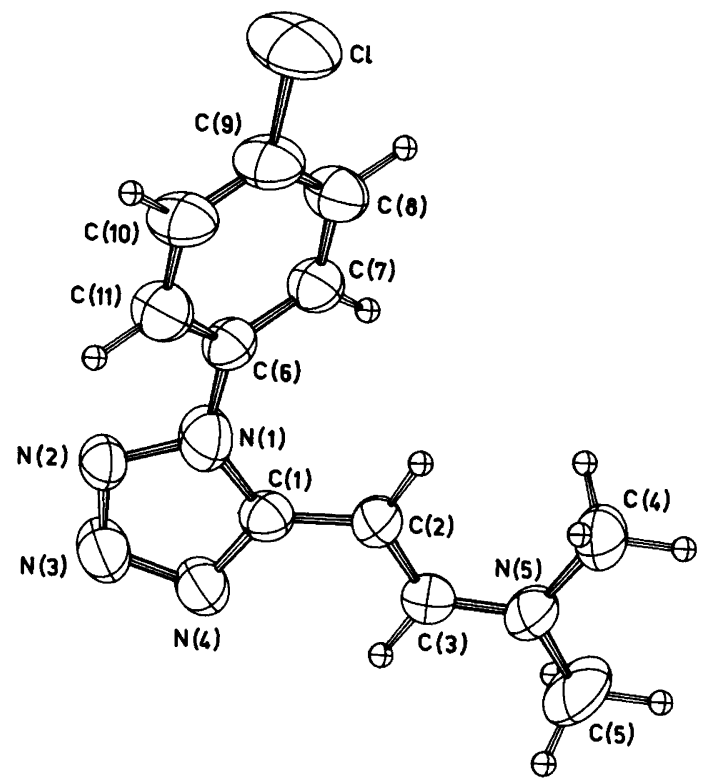

Fig. 1. ORTEP4 drawing of $\mathrm{C}_{11} \mathrm{H}_{12} \mathrm{CIN}_{5}$ with the numbering of the atoms in the molecule. Thermal ellipsoids for the nonhydrogen atoms are drawn at the $50 \%$ probability level.

$\AA]$. The $\mathrm{N}(2)-\mathrm{N}(3)$ bond [1.287(3) $\AA]$ is the shortest bond distance in the tetrazole ring, and is close to a pure $\mathrm{N}=\mathrm{N}$ double bond $(1.24 \AA) .{ }^{6}$ Similar bond lengths have been found in other tetrazole derivatives. ${ }^{7-9}$

The tetrazole ring is planar, with none of the atoms deviating more than one standard deviation $(0.002 \AA)$ from the plane. The dihedral angle between the tetrazole ring

Table 2. Bond lengths $(\AA)$ and selected bond angles $\left(^{\circ}\right)$ in $\mathrm{C}_{11} \mathrm{H}_{12} \mathrm{CIN}_{5}$. Estimated standard deviations are given in parentheses.

\begin{tabular}{llll}
\hline $\mathrm{Cl}-\mathrm{C}(9)$ & $1.737(3)$ & $\mathrm{N}(5)-\mathrm{C}(4)$ & $1.458(4)$ \\
$\mathrm{N}(1)-\mathrm{N}(2)$ & $1.364(3)$ & $\mathrm{N}(5)-\mathrm{C}(5)$ & $1.437(4)$ \\
$\mathrm{N}(1)-\mathrm{C}(1)$ & $1.360(3)$ & $\mathrm{N}(1)-\mathrm{C}(6)$ & $1.426(3)$ \\
$\mathrm{N}(1)-\mathrm{C}(6)$ & $1.426(3)$ & $\mathrm{C}(6)-\mathrm{C}(7)$ & $1.379(4)$ \\
$\mathrm{N}(2)-\mathrm{N}(3)$ & $1.287(3)$ & $\mathrm{C}(7)-\mathrm{C}(8)$ & $1.375(4)$ \\
$\mathrm{N}(3)-\mathrm{N}(4)$ & $1.351(3)$ & $\mathrm{C}(8)-\mathrm{C}(9)$ & $1.380(4)$ \\
$\mathrm{N}(4)-\mathrm{C}(1)$ & $1.335(3)$ & $\mathrm{C}(9)-\mathrm{C}(10)$ & $1.371(5)$ \\
$\mathrm{C}(1)-\mathrm{C}(2)$ & $1.421(4)$ & $\mathrm{C}(10-\mathrm{C}(11)$ & $1.378(4)$ \\
$\mathrm{C}(2)-\mathrm{C}(3)$ & $1.349(4)$ & $\mathrm{C}(11)-\mathrm{C}(6)$ & $1.385(4)$ \\
$\mathrm{N}(5)-\mathrm{C}(3)$ & $1.335(4)$ & & \\
& & & \\
$\mathrm{C}(1)-\mathrm{N}(1)-\mathrm{N}(2)$ & $108.5(2)$ & $\mathrm{C}(3)-\mathrm{N}(5)-\mathrm{C}(5)$ & $121.5(3)$ \\
$\mathrm{N}(2)-\mathrm{N}(1)-\mathrm{C}(6)$ & $118.8(2)$ & $\mathrm{C}(4)-\mathrm{N}(5)-\mathrm{C}(5)$ & $118.0(3)$ \\
$\mathrm{C}(1)-\mathrm{N}(1)-\mathrm{C}(6)$ & $132.6(3)$ & $\mathrm{N}(1)-\mathrm{C}(6)-\mathrm{C}(7)$ & $121.3(3)$ \\
$\mathrm{N}(1)-\mathrm{N}(2)-\mathrm{N}(3)$ & $106.1(3)$ & $\mathrm{N}(1)-\mathrm{C}(6)-\mathrm{C}(11)$ & $118.1(3)$ \\
$\mathrm{N}(2)-\mathrm{N}(3)-\mathrm{N}(4)$ & $111.7(3)$ & $\mathrm{C}(7)-\mathrm{C}(6)-\mathrm{C}(11)$ & $120.5(3)$ \\
$\mathrm{N}(3)-\mathrm{N}(4)-\mathrm{C}(1)$ & $106.7(3)$ & $\mathrm{C}(6)-\mathrm{C}(7)-\mathrm{C}(8)$ & $119.9(3)$ \\
$\mathrm{N}(4)-\mathrm{C}(1)-\mathrm{N}(1)$ & $107.0(3)$ & $\mathrm{C}(7)-\mathrm{C}(8)-\mathrm{C}(9)$ & $119.1(3)$ \\
$\mathrm{N}(4)-\mathrm{C}(1)-\mathrm{C}(2)$ & $126.5(3)$ & $\mathrm{C}(8)-\mathrm{C}(9)-\mathrm{Cl}$ & $119.1(3)$ \\
$\mathrm{N}(1)-\mathrm{C}(1)-\mathrm{C}(2)$ & $126.5(3)$ & $\mathrm{C}(8)-\mathrm{C}(9)-\mathrm{C}(10)$ & $121.5(3)$ \\
$\mathrm{C}(1)-\mathrm{C}(2)-\mathrm{C}(3)$ & $120.3(3)$ & $\mathrm{C}(10)-\mathrm{C}(9)-\mathrm{Cl}$ & $119.4(3)$ \\
$\mathrm{C}(2)-\mathrm{C}(3)-\mathrm{N}(5)$ & $126.8(3)$ & $\mathrm{C}(9)-\mathrm{C}(10)-\mathrm{C}(11)$ & $119.4(3)$ \\
$\mathrm{C}(3)-\mathrm{N}(5)-\mathrm{C}(4)$ & $119.8(3)$ & $\mathrm{C}(10)-\mathrm{C}(11)-\mathrm{C}(6)$ & $119.5(3)$ \\
\hline
\end{tabular}


and the phenyl ring is $36.5(1)^{\circ}$. The atoms of the aminovinyl group deviate slightly from the tetrazole plane, the deviations from this plane are: $\mathrm{C}(3) 0.11, \mathrm{~N}(5) 0.12, \mathrm{C}(2)$ $0.01 \AA$, respectively.

\section{References}

1. Fischer, G. W. and Herrmann, M. J. Prakt. Chem. 331 (1989). In press.

2. Gilmore, G. J. J. Appl. Crystallogr. 17 (1984) 42.

3. Mallinson, P. R. and Muir, K. W. J. Appl. Crystallogr. 18 (1985) 51.

4. Johnson, C. K. ORTEP-II: A Fortran Thermal Ellipsoid Plot Program for Crystal Structure Illustrations, Report
ORNL-3794, Oak Ridge National Laboratory, Oak Ridge, TN 1971.

5. Schroeder, M. A., Makino, R. C. and Tolles, W. M. Tetrahedron 29 (1973) 3463.

6. Mitchell, A. D. and Cross, L. C. Tables of Interatomic Distances and Configuration in Molecules and Ions, Special Publ. No. 11, The Chemical Society, London 1958.

7. Britts, K. and Karle I. L. Acta Crystallogr. 22 (1967) 308.

8. Bryden, J. H. Acta Crystallogr. 11 (1958) 31.

9. Palenik, G. J. Acta Crystallogr. 16 (1963) 596.

Received September 13, 1988. 